\title{
Factors affecting to the Quality of Korean Soybean Paste, Doenjang
}

\author{
Hye-Jeoung Shim ${ }^{1} \cdot$ Jeong-hyun Yun ${ }^{2} \cdot$ Kyung-Hee $\operatorname{Koh}^{1}$ (D) \\ 한국 된장의 품질에 영향을 미치는 요인
}

심혜정 ${ }^{1} \cdot$ 윤정현 $^{2} \cdot$ 고경희 ${ }^{1}$

Received: 28 August 2018 / Accepted: 28 October 2018 / Published Online: 31 December 2018

(C) The Korean Society for Applied Biological Chemistry 2018

\begin{abstract}
The quality of Korean doenjang, which was traditionally made for this study, was monitored for physicochemical properties, antioxidant capacity, and sensory properties at six months intervals for three years. The collected data were comprehensively analyzed using the $k$-means clustering via principal component analysis (PCA) to determine the optimal intake duration and sensory factors associated with acceptance. Doenjang samples were classified with every year interval based on PCA, and then the classified doenjang samples were further grouped into cluster one, two, and three based on the $k$-means clustering. In Cluster three, doenjang that was aged for thirty and thirty-six months, respectively, showed high total phenolic content, antioxidant capacity, superoxide dismutase like activity, and 2,2-diphenyl-1picryl-hydrazyl radical scavenging capacity. Interestingly, along with acceptance, the levels of free amino acids and organic acids were higher in Cluster 3. The sensory factors found to be associated with acceptance included umami taste and brown color. In conclusion, this study proposes the intake of doenjang aged for thirty months based on its antioxidant activity and sensory properties although doenjang is usually ready after twelve months of aging.
\end{abstract}

Kyung-Hee Koh $(\bowtie)$

E-mail: verokoh@catholic.ac.kr

${ }^{1}$ Department of Food Science and Nutrition, The Catholic University of Korea, 43 Jibong-ro, Wonmi, Bucheon, Gyeonggi 14662, Republic of Korea

${ }^{2}$ Department of Food Biotechnology, Korea University of Science and Technology, Daejeon 34113, Republic of Korea

This is an Open Access article distributed under the terms of the Creative Commons Attribution Non-Commercial License (http://creativecommons. org/licenses/by-nc/3.0/) which permits unrestricted non-commercial use, distribution, and reproduction in any medium, provided the original work is properly cited.
Keywords Antioxidant capacity $\cdot$ Doenjang $\cdot$ Korean soybean paste $\cdot$ Sensory evaluation $\cdot$ Quality factors

\section{서 론}

한국의 전통발효식품인 된장은 기원전 550 년경 중국의 「제민 요술(Qimin Yaoshu)」에 두장(豆醬)으로 기록되어 있으며, 한국 의「삼국사기(Samguk Sagi)」에는 683년 신문왕의 혼수 품목 으로 장(醬)이 기록되어 있다[1]. 한국인이 오랫동안 섭취해 온 된장과 관련된 in vitro 연구에서, 된장의 물 추출물은 human gastric adenocarcinoma cell (AGS) human colon cancer cell (HT-29)과 human hepatocellular carcinoma cell (Hep 3B)에 항암효과를 나타내었다[2,3]. Jung들의 in vivo 연구에서, 된장의 물 추출물은 고형 종양을 주입시킨 mice colon 26-M3.1 cell의 대장암 억제 효과를 발표하였다[4]. 또한 된장에서 추출된 7,3,4trihydroxyisoflavone은 고지방 식이를 한 쥐의 3T3-L1 cells에서 항 비만 효과와 된장 발효 중 isoflavone의 아그리콘인 genistein과 daidzein, 그리고 amino acids와 peptides 등의 항산 화 작용을 시사하였다[5,6]. 된장의 숙성기간과 관능적 특성에 관한 연구에서, 중추신경계의 억제성 신경전달물질인 $\gamma$ aminobutyric acid (GABA)의 함량은 10 년 숙성된 시판 된장이 숙성 전 보다 77 배 증가하였다[7]. 또한 시판 된장의 총 페놀 화합물 함량 및 1,1-diphenyl-2-picryl-hydrazyl (DPPH), 2,2'Azino-bis (3-ethylbenzthiazoline-6-sulfonic acid) (ABTS) radical scavenging activity 등은 5년 동안 지속적으로 증가하였고, 이 후 30년 동안에도 높은 항산화 활성이 유지되었다고 보고하였 다[8].

최근에는 주성분 분석(principal component analysis, PCA)방 법으로 된장의 품질을 평가하는 연구들이 발표되었다. $\mathrm{Ku}$ 등[9] 은 9년 숙성된 구입 된장을 정량적 묘사분석과 군집 분석으로 
관능적인 품질을 평가하였다. Tian 등과 Lee 등의 연구는 된장 의 이화학적 성분과 관능 특성, 그리고 당과 아미노산 등과의 관련성을 종합적으로 분석하여 된장의 품질을 평가하였다 $[10$, 11]. 이들 선행연구들의 경우 대부분 숙성기간이 다른 시판 된 장을 각각 구입하여 실험한 연구로, 일관성 있게 발효 초기부 터 숙성기간 동안 된장 성분들의 총체적인 변화를 모니터링한 분석이 아니므로 이들을 비교하기에는 한계를 가지고 있다.

본 연구에서는 전통적인 방법으로 직접 제조한 된장을 6개월 간격으로 채취하여 3 년 동안 모니터링 하였다. 된장의 이화학 적 성분, 항산화력과 관능평가를 통하여 된장의 최적 섭취시기 를 설정하였고, 서로 관련성이 있는 요인들을 밝히고자 하였다. 우선 된장의 아미노산, 유리당, 유기산, 지방산과 무기질 등의 이화학적 성분 분석과 총 페놀, $\mathrm{DPPH}, \mathrm{ABTS}$ 라디칼 소거력, $\mathrm{SOD}$ 유사활성 등의 기능성과 관련된 항산화력을 실험하였다. 다음으로 기호도에 영향을 주는 관능 요인들을 다중회귀분석 (multiple-regression analysis)으로 선별하여 기호도를 예측하는 주요 요인들을 밝혔다. 마지막으로 주성분 분석과 $k$-평균 $(k-$ means cluster analysis)으로 숙성 기간 동안 된장의 종합적인 품질을 분석하고 평가하여, 된장 품질에 영향을 주는 요인들을 도출하였다.

\section{재료 및 방법}

\section{실험재료}

된장은 Park 등[12] 방법의 전통 된장 표준제조방법을 따라 대 두 (Glycin max L.)를 사용하여 직접 제조하였다. 된장은 옹기 에 넣어 자연조건에서 36 개월 동안 연평균 $13.4 \pm 0.2{ }^{\circ} \mathrm{C}$ 에서 발 효 저장하면서 6개월 간격으로 시료를 채취하여 분석하였다 본 연구의 항산화력 실험을 위해 사용된ABTS, DPPH, ferrous chloride, Folin-Ciocalteu's reagent은 Sigma-Aldrich (Steinheim, Germany) 제품을 사용하였다. Aluminum nitrate, gallic acid and pyrogallol은 Sigma (St. Louis, MO, USA) 제품을, 1Naphthylamine은 Sigma (Tianjin, China) 제품을, Linoleic acid 은 Sigma (Steinheim) 제품을 사용하였다. Sugars, ascorbic acid, organic acids, amino acids은 Sigma-Aldrich (St. Lou, $\mathrm{MO}, \mathrm{USA}$ ) 제품을 구입하여 사용하였다.

\section{일반성분, $\mathrm{pH}$ 와 적정산도}

일반성분은 식품공전[13]을 따라 분석하였다. $\mathrm{pH}$ 와 총산도는 Chang 등의 방법[14]을 응용하였다. $\mathrm{pH}$ 는 시료 $4 \mathrm{~g}$ 에 증류수 $40 \mathrm{~mL}$ 를 넣고 측정하고, $0.1 \mathrm{~N} \mathrm{NaOH}$ 표준용액으로 적정산도를 구하였다.

\section{유리당 분석}

유리당은 식품공전의 당류 분석 방법[13]을 응용하였다. 된장은 증류수 추출물을 $0.45 \mu \mathrm{m}$ membrane filter로 여과하여 실험용액 으로 만들었다. 유리당은 Refractive Index detector (RI, Agilent, Palo Aito, CA, USA)가 장착된 HPLC (Agilent 1200 series, Palo Aito, CA, USA)로 carbohydrate high performance column $(250 \mathrm{~mm} \times 4.6 \mathrm{~mm} \times 4 \mu \mathrm{m}$, Waters, Milford, USA)을 사용하여 분석하였다. 이동상은 distilled water : acetonitrile $=17: 83$ (v:v)
로, 속도는 $1.0 \mathrm{~mL} / \mathrm{min}$ 으로 분석하였다. 실험 용액 및 표준 용 액을 각각 $10 \mu \mathrm{L}$ 씩 주입하였다.

\section{유기산 분석}

유기산 분석은 Do 등의 방법[15]을 변형하여 사용하였다. 된장 시료는 증류수로 추출하여 Sepak C18 cartridge로 정제하고 $0.45 \mu \mathrm{m}$ membrane filter로 여과하여 UV-DAD가 장착된 HPLC (Agilent 1200 series, Palo Aito, CA, USA)로 분석하 였다. 이때 column은 ZORBAX SB-Aq (C18 Column, 4.6 $\mathrm{mm} \times 150 \mathrm{~mm} \times 5 \mu \mathrm{m}$, Alltech, Deerfield, IL, USA)를 사용하 였다. 이동상은 $\mathrm{pH} 2.0$ 인 $20 \mathrm{mM}$ aqueous phosphate buffer: acetonitrile $=99: 1$ (v:v)이였으며, 주입량은 $10.0 \mu \mathrm{L}$ 이였다. 속도 는 $1.0 \mathrm{~mL} / \mathrm{min}$, 칼럼의 오븐 온도는 $25^{\circ} \mathrm{C}$, 흡광도는 $210 \mathrm{~nm}$ 에 서 측정하였다.

\section{지방산 분석}

지방산은 Kang 의 방법[16]을 응용하여 분석하였다. 지방산 분 석에는 flame ionization detector가 장착된 Gas Chromatography (Agilent 6890, Waldbronn, Germany)를 사용하여 DB wax capillary column $(0.25 \mu \mathrm{m} \times 30 \mathrm{~m}, 0.32 \mathrm{~mm})$ 으로 분석하였다. 주입부의 온도는 $230{ }^{\circ} \mathrm{C}$, 검출기의 온도는 $250{ }^{\circ} \mathrm{C}$ 으로 설정하였 다. 오븐 온도는 $165^{\circ} \mathrm{C}$ 에서 1 분간 유지한 후 $2{ }^{\circ} \mathrm{C} / \mathrm{min}$ 의 비율 로 $200^{\circ} \mathrm{C}$ 까지 상승시켜 25 분 유지시켰다. Carrier gas는 $\mathrm{N}_{2}$ 를 사용하였다. 시료의 속도는 $1.0 \mathrm{~mL} / \mathrm{min}$, 주입량은 $1 \mu \mathrm{L}$ 였다. 지 방산 함량은 Supelco Co. (St. Louis, Mo, USA)의 Fatty Acids Methyl Esters mix를 사용하여 지방산의 규정화된 면적 보정백분법(normalized area \%법)으로 계산하였다.

\section{유리아미노산 분석}

유리아미노산은 식품공전의 방법[13]을 응용하였다. 시료는 0.1 $\mathrm{N} \mathrm{HCl}$ 에 용해하여 $0.45 \mu \mathrm{m}$ membrane filter (Millipore Co., Billerica, MA, USA) 로 여과하여 UV-DAD가 장착된 Agilent 1100 series HPLC (Waldbronn, Germany)로, ZORBAX column $(4.6 \mathrm{~mm} \times 150 \mathrm{~mm} \times 3.5 \mu \mathrm{m})$ 을 사용하여 분석하였다. 유리아미 노산은 $o$-Phthal dialdehyde로 자동 유도체화되어, $338 \mathrm{~nm}$ 의 $\mathrm{UV}$ 에서 검출되었다. 이동상 $\mathrm{A}$ 용액 $40 \mathrm{mM}$ phosphate buffer $(\mathrm{pH}$ 7.8)와 $\mathrm{B}$ 용액 methanol : acetonitrile : water $=45: 45: 10$ (v:v:v) 으로, 초기에 $\mathrm{A}$ 와 $\mathrm{B}$ 의 비율을 $100 \%: 0 \%$ 으로 시작하여 1.9 $\min$ 에 $43 \%: 57 \%, 18.1 \mathrm{~min}$ 에 $0 \%: 100 \%, 22.3 \mathrm{~min}$ 에 $100 \%: 0 \%$ 로 설정하고 26 분까지 $100 \%: 0 \%$ 의 비율로 분석하였다. 속도는 $2.0 \mathrm{~mL} / \mathrm{min}$ 였고, 시료의 주입은 $0.5 \mu \mathrm{L}$ 이였다.

\section{항산화력}

총 페놀 함량은 Folin-Ciocalteu method을 사용하여 gallic acid equivalents (GAE) $\mathrm{mg} / \mathrm{L}$ 로 나타내었다[17]. DPPH 라디칼 소거 력은 Kang 등[16], ABTS 라디칼 소거력은 Verzelloni 등의 방 법[18], 환원력은 $\mathrm{Xu}$ 등의 방법[19]을 응용하여 사용하였다. 지 질과산화 억제력은 ferric thiocyanate 방법으로 측정하였다[20]. 아질산염 소거력은 $\mathrm{pH} 1.2,3.0,6.0$ 에서 Griess test로 분석하 였고, SOD (superoxide dismutase) 유사 활성은 pyrogallol을 사용하여 $\operatorname{Lim}$ 등의 방법[21]을 응용하여 측정하였다. 


\section{관능검사와 색도}

숙성 기간 동안 된장의 관능적 품질 평가는 훈련된 패널 15 명 을 대상으로 용어를 선정하였다. 정량적 묘사분석(quantitative descriptive analysis, QDA)과 기호도 측정은 $15 \mathrm{~cm}$ 선 척도의 방법으로 항목 특성의 강도를 표시하도록 했다[22,23]. 색도는 Hutchings의 방법을 따라 Hunter value로 나타냈다[24].

\section{통계분석}

데이터의 유의성 검증은 SAS (SAS 9.3, Cary, NC, USA)와 SIMCA (SIMCA, version 12, Umetrics, Umea, Sweden)을 이용하여 ANOVA (one-way analysis of variance) 분석 후 Duncan's multiple range test로 $p<0.01$ 수준에서 검증하였다. 모든 분석 결과는 주성분분석과 $k$-means 군집분석 $(k$-means clustering)을 하였다[25]. PCA 로 여러 개의 변수를 2개의 중 요한 주성분(principle component, PC)으로 축소하여 데이터의 전체 변수 사이의 관계를 분석하였다. $k$-means는 비계층적 군 집(nonhierarchical clustering) 방법으로 36개월 동안 숙성한 된 장에서 얻은 데이터를 크러스터(cluster)로 분류하였다.

\section{결과 및 고찰}

\section{일반성분 특성}

된장의 일반성분은 Table 1 에 제시하였다. 된장의 수분 함량은 숙성 전에는 $58.4 \%$ 이였으며, 숙성 후기인 36 개월에는 $38.8 \%$ 로 감소하였다. 탄수화물은 $12.8-16.6 \%$, 조단백질은 $13.1-14.9 \%$, 조 회분은 14.3-21.4\%이였고, 염도는 12.9-19.5\%으로 나타났다. 숙 성기간 동안 수분이 감소하는 경향을 나타내어, 수분을 제외한 건조물량으로 구하였다. 탄수화물은 $30.8-27.1 \%$, 조단백질은 $31.5-26.6 \%$ 였고, 조회분과 염도는 숙성 기간에 따른 유의적인 변화가 없었다 $(p<0.01)$. 이는 $\mathrm{Ku}$ 등[9]이 1년에서 9년까지 숙 성 기간별 일반성분을 분석한 결과 숙성 기간에 따른 경향은 보이지 않았다는 결과와 유사하였다. 된장의 전통식품품질 인증 규격 기준[26] 지표인 아미노태 질소 함량을 분석하였다. 숙성 전과 숙성 후의 아미노태 질소 함량은 각각 $0.4 \%$ 와 $0.6 \%$ 로 나 타나 된장의 인증 규격인 $0.3 \%$ 이상으로 품질 기준에 적합함 을 확인하였다.

\section{$\mathrm{pH}$ 와 적정산도}

Table 1 에서 된장의 $\mathrm{pH}$ 는 숙성 전 $6.7 \pm 0.1$ 에서 숙성 후기 36 개 월에 $\mathrm{pH} 4.7 \pm 0.0$ 이였다. 총산도는 숙성 전 $3.4 \pm 0.1 \%$ 에서 숙성 후기 36 개월에 $7.5 \pm 0.0 \%$ 로 숙성기간이 길수록 증가하였다 $(p$ $<0.01) . \mathrm{pH}$ 의 감소와 총산도의 증가는 발효 숙성 중 미생물에 의한 유기산 생성에 기인하였다[27,28].

\section{유리당, 유기산, 지방산과 유리아미노산}

Table 1에서 된장의 유리당은 arabinose, glucose와 galactose가 검출되었다. 숙성과정 동안 미생물의 탄소원으로 사용된 유리당 은 오탄당인 arabinose가 가장 먼저 소모되어 24개월 이후에는 검출되지 않았다. 육탄당인 glucose와 galactose의 경우에는 대 두 탄수화물의 가수분해 및 합성 등으로 함량의 증감이 일정하 지 않으나, 된장의 숙성 후기인 30 개월 이후에는 검출되지 않
았다 $(p<0.01)$. 이들 유리당은 미생물의 탄소 영양원 및 된장의 갈색화 반응 등에 참여하여 감소한 것으로 보인다[29]. 유기산 의 경우, 숙성 전 된장에서는 fumaric acid 와 acetic acid가 검 출되었다. malic acid는 숙성 후기인 30개월에 7257.1 \pm 111.5 $\mathrm{mg} / 100 \mathrm{~g}$ 로 높게 나타났고, 36개월에는 약간 감소하는 경향을 나타냈다. 반면에 lactic acid는 된장 숙성과정 중에 꾸준하게 증 가하여 숙성 36 개월에 $27597.2 \pm 344.3 \mathrm{mg} / 100 \mathrm{~g}$ 으로 나타났다 $(p$ $<0.01)$. 이는 숙성 후기에는 된장과 관련된 lactic acid fermentation 에 의한 lactic acid 생성, 그리고 malo-lactic fermentation으로 일부 malic acid가 lactic acid로 전환된 것으로 보인다. 된장의 주요 유기산은 lactic acid과 malic acid이 대부분을 차지하고 있는 것으로 나타났다. 대두 발효식품에서 lactic acid는 중요한 유기산으로, 한국의 전통 된장 뿐 만 아니라, 일본의 miso, 중 국의 sufu 등에서도 주요 유기산으로 보고되었다[30,31]. 또한 Yoon 등은 lactic acid와 malic acid는 된장의 신맛에 영향을 줄 뿐만 아니라 $\mathrm{pH}$ 을 낮추어 보존성에도 중요한 역할을 하는 것으로 알려졌다[32]. 지방산 조성에서 주요 불포화지방산인 linoleic acid와 linolenic acid는 숙성 기간 동안 전체 지방산의 $60 \%$ 이상의 높은 비율을 나타냈다. 된장에서 이들 지방산의 조 성은 10 년 숙성기간 동안 $60 \%$ 이상으로 거의 변화가 일어나지 않았으며 이는 된장의 항산화 활성과 관련이 있다고 하였다[7].

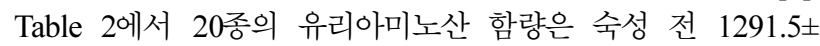
$28.2 \mathrm{mg} / 100 \mathrm{~g}$ 에서 숙성 후기 36개월에 $29300.2 \pm 169.0 \mathrm{mg} / 100 \mathrm{~g}$ 으로 증가하였다 $(p<0.01)$. 라디칼 소거 아미노산인 cysteine, histidine, methionine, phenylalanine, tyrosine, tryptophane [33] 의 함량은 숙성 기간 동안 15 배 증가하였고, 필수 아미노산인 valine, leucine, isoleucine, methionine, threonine, lysine, phenylalanine, tryptophane과 histidine의 총 함량도 숙성기간 동 안 20 배 이상 증가하였다 $(p<0.01)$.

\section{항산화력}

된장의 항산화력은 Table 3에 제시하였다. 된장의 총 페놀 함 량은 숙성 전에는 $1912.6 \pm 32.8 \mathrm{mg} / \mathrm{L}$ 에서 숙성후기 $5179.1 \pm 197.3$ $\mathrm{mg} / \mathrm{L}$ 으로 증가하였다 $(p<0.01)$. Kwon 등은 된장의 총 페놀에 의한 항산화 효과는 발효 과정 중 isoflavone의 배당체가 $\beta$ glucosidase에 의해 aglycone 형태인 genistein과 daidzei의 함량 이 증가하기 때문이라고 시사하였다[34]. ABTS 라디칼 소거력 은 숙성 전 $93.4 \pm 0.6 \%$ 였고, 숙성 후기 36 개월에는 $89.7 \pm 0.1 \%$ 으로 감소하였다 $(p<0.01)$. DPPH 라디칼 소거력, $\mathrm{SOD}$ 유사활 성, 아질산염 소거력은 숙성 후기에 높게 나타났다. DPPH 라 디칼 소거력은 숙성전 $95.1 \pm 0.5 \%$ 에서 숙성 후기인 36 개월에 $98.8 \pm 1.1 \%$ 였고, SOD 유사활성은 $74.4 \pm 1.9 \%$ 에서 $86.4 \pm 1.7 \%$ 로 나타났다 $(p<0.01)$. 체내에서 nitrosamine 생성을 억제와 관련된 아질산염 소거력은 $\mathrm{pH} \quad 1.2>\mathrm{pH} \quad 3.0>\mathrm{pH} 6.0$ 순으로 $\mathrm{pH}$ 가 낮 을수록 높은 소거력을 나타내었다 $(p<0.01)$. Lim 등도 Phyllostachys bambusoides에서도 아질산염 소거력이 산성에서 높게 나타났음 을 시사하였다[21]. 본 연구에서는 총 페놀 함량과 ABTS라디 칼 소거력, DPPH 라디칼 소거력, 환원력과 지질과산화억제력 은 상관성을 나타내지 않았으나 총 페놀 함량과 SOD 유사활 성, 총 페놀 함량과 아질산염 소거력의 상관계수는 각각 0.792 와 0.811 로 유의성을 나타내었다 $(p<0.05)$. Chai 등의 연구에서 도 총 페놀 함량과 $\mathrm{DPPH}$ 라디칼 소거력의 상관관계를 나타내 
Table 1 Proximate compositions and physicochemical propertiesof Doenjang

\begin{tabular}{|c|c|c|c|c|c|c|c|}
\hline & \multicolumn{7}{|c|}{ Doenjang (Aging period, month) } \\
\hline & \multirow{2}{*}{ Before aging } & \multicolumn{2}{|c|}{ Initial phase } & \multicolumn{2}{|c|}{ Mid phase } & \multicolumn{2}{|c|}{ Final phase } \\
\hline & & 6 & 12 & 18 & 24 & 30 & 36 \\
\hline \multicolumn{8}{|c|}{ Proximate compositions (\%) } \\
\hline Moisture & $58.4 \pm 0.1 \mathrm{a}$ & $54.0 \pm 0.1 \mathrm{c}$ & $55.2 \pm 0.1 \mathrm{~b}$ & $47.2 \pm 0.2 \mathrm{~d}$ & $40.2 \pm 0.2 \mathrm{f}$ & $43.3 \pm 0.2 \mathrm{e}$ & $38.8 \pm 0.3 \mathrm{~g}$ \\
\hline Carbohydrate & $12.8 \pm 1.0 \mathrm{~d}$ & $14.4 \pm 1.2 \mathrm{c}$ & $11.8 \pm 1.2 \mathrm{e}$ & $16.6 \pm 0.2 b$ & $18.5 \pm 0.2 \mathrm{a}$ & $14.8 \pm 0.0 \mathrm{c}$ & $16.6 \pm 0.9 b$ \\
\hline Crude protein & $13.1 \pm 0.8 \mathrm{c}$ & $14.4 \pm 1.3 \mathrm{~b}$ & $13.4 \pm 1.3 \mathrm{c}$ & $14.1 \pm 0.4 \mathrm{~b}$ & $14.9 \pm 0.1 \mathrm{a}$ & $15.1 \pm 0.5 \mathrm{a}$ & $14.9 \pm 0.9 \mathrm{a}$ \\
\hline Crude lipid & $1.3 \pm 0.1 \mathrm{e}$ & $1.0 \pm 0.1 \mathrm{e}$ & $2.5 \pm 0.1 \mathrm{~d}$ & $3.7 \pm 0.1 \mathrm{c}$ & $3.9 \pm 0.2 \mathrm{c}$ & $6.3 \pm 0.2 b$ & $8.3 \pm 0.3 \mathrm{c}$ \\
\hline Crude ash & $14.3 \pm 0.0 \mathrm{~g}$ & $16.1 \pm 0.0 \mathrm{f}$ & $17.0 \pm 0.0 \mathrm{e}$ & $18.4 \pm 0.1 \mathrm{~d}$ & $22.6 \pm 0.1 \mathrm{a}$ & $20.5 \pm 0.2 \mathrm{c}$ & $21.4 \pm 0.1 \mathrm{~b}$ \\
\hline \multicolumn{8}{|c|}{ Physicochemical properties } \\
\hline $\mathrm{pH}$ & $6.7 \pm 0.1 \mathrm{a}$ & $4.9 \pm 0.0 \mathrm{cb}$ & $4.8 \pm 0.0 \mathrm{e}$ & $4.8 \pm 0.0 \mathrm{~d}$ & $5.0 \pm 0.0 \mathrm{~b}$ & $4.9 \pm 0.0 \mathrm{~cd}$ & $4.7 \pm 0.0 \mathrm{e}$ \\
\hline Total acidity $(\%)$ & $3.4 \pm 0.1 \mathrm{~d}$ & $6.9 \pm 0.6 \mathrm{c}$ & $8.3 \pm 0.7 \mathrm{a}$ & $7.3 \pm 0.5 \mathrm{c}$ & $7.6 \pm 0.0 \mathrm{~b}$ & $7.5 \pm 0.0 \mathrm{~b}$ & $7.5 \pm 0.0 \mathrm{~b}$ \\
\hline Salinity $(\%)$ & $12.9 \pm 0.0 \mathrm{e}$ & $15.3 \pm 0.3 \mathrm{~d}$ & $18.2 \pm 1.6 \mathrm{c}$ & $17.8 \pm 0.0 \mathrm{c}$ & $21.5 \pm 0.1 \mathrm{a}$ & $19.6 \pm 0.1 \mathrm{~b}$ & $19.5 \pm 0.0 \mathrm{~b}$ \\
\hline \multicolumn{8}{|c|}{ Free sugars $(\mathrm{mg} / 100 \mathrm{~g})$} \\
\hline Galactose & $0.39 \pm 0.05 \mathrm{cA}$ & $0.46 \pm 0.03 \mathrm{cA}$ & $0.38 \pm 0.04 \mathrm{cA}$ & $1.58 \pm 0.68 \mathrm{bA}$ & $3.98 \pm 1.04 \mathrm{aA}$ & ND & ND \\
\hline Glucose & $0.45 \pm 0.02 \mathrm{bBA}$ & $0.26 \pm 0.01 \mathrm{cB}$ & $0.05 \pm 0.00 \mathrm{dBC}$ & $0.53 \pm 0.06 \mathrm{abB}$ & $0.41 \pm 0.00 \mathrm{bB}$ & ND & ND \\
\hline Arabinose & $0.16 \pm 0.02 \mathrm{bB}$ & $0.05 \pm 0.01 \mathrm{dC}$ & $0.08 \pm 0.01 \mathrm{cB}$ & $0.91 \pm 0.00 \mathrm{aAB}$ & ND & ND & ND \\
\hline Total & $0.99 \pm 0.07 \mathrm{c}$ & $0.76 \pm 0.04 \mathrm{c}$ & $0.54 \pm 0.05 \mathrm{c}$ & $3.01 \pm 0.74 b$ & $4.46 \pm 1.06 \mathrm{a}$ & ND & ND \\
\hline \multicolumn{8}{|c|}{ Organic acids (mg/100 g) } \\
\hline Citric acid & ND & ND & $74.9 \pm 1.8 \mathrm{bB}$ & ND & ND & ND & ND \\
\hline Malic acid & ND & ND & ND & ND & ND & $7257.1 \pm 111.5 \mathrm{aA}$ & $5807.3 \pm 7.4 \mathrm{bB}$ \\
\hline Oxalic acid & ND & ND & ND & $53.8 \pm 0.0 \mathrm{aC}$ & $48.7 \pm 0.2 \mathrm{bD}$ & ND & ND \\
\hline Succinic acid & ND & ND & ND & ND & ND & ND & ND \\
\hline Formic acid & ND & ND & ND & $169.1 \pm 0.5 \mathrm{aB}$ & $161.5 \pm 1.5 \mathrm{bB}$ & ND & ND \\
\hline Lactic acid & ND & ND & $451.8 \pm 11.2 \mathrm{dA}$ & $977.6 \pm 5.6 \mathrm{cA}$ & $861.2 \pm 4.4 \mathrm{cA}$ & $22705.5 \pm 0.1 \mathrm{bB}$ & $27597.2 \pm 344.3 \mathrm{aA}$ \\
\hline Fumaricacid & $29.9 \pm 1.2 \mathrm{bB}$ & $36.6 \pm 1.6 \mathrm{aB}$ & ND & ND & ND & ND & ND \\
\hline Acetic acid & $148.0 \pm 5.2 \mathrm{bA}$ & $316.4 \pm 10.4 \mathrm{aA}$ & ND & $59.3 \pm 0.4 \mathrm{cC}$ & $66.5 \pm 0.1 \mathrm{cC}$ & ND & ND \\
\hline Total & $178.0 \pm 4.9 \mathrm{e}$ & $353.0 \pm 8.9 \mathrm{de}$ & $526.7 \pm 9.6 \mathrm{~d}$ & $1259.8 \pm 5.7 \mathrm{c}$ & $1137.9 \pm 5.8 \mathrm{c}$ & $29962.5 \pm 111.6 b$ & $33404.5 \pm 351.7 \mathrm{a}$ \\
\hline \multicolumn{8}{|c|}{ Fatty acids (peak area \%) } \\
\hline Palmitic acid & $14.0 \pm 1.5 \mathrm{aC}$ & $12.5 \pm 0.3 \mathrm{bC}$ & $12.1 \pm 0.0 \mathrm{bC}$ & $13.1 \pm 0.2 \mathrm{abC}$ & $12.6 \pm 0.2 b C$ & $10.5 \pm 0.2 \mathrm{cC}$ & $11.1 \pm 0.1 \mathrm{cC}$ \\
\hline Stearic acid & $4.6 \pm 0.3 \mathrm{aD}$ & $4.2 \pm 0.1 \mathrm{bcD}$ & $3.9 \pm 0.1 \mathrm{cdD}$ & $4.3 \pm 0.0 \mathrm{bD}$ & $4.1 \pm 0.1 \mathrm{bcD}$ & $3.4 \pm 0.2 \mathrm{eD}$ & $3.8 \pm 0.1 \mathrm{dE}$ \\
\hline Oleic acid & $20.0 \pm 1.0 \mathrm{abB}$ & $19.9 \pm 0.1 \mathrm{bB}$ & $20.7 \pm 0.1 \mathrm{aB}$ & $20.4 \pm 0.1 \mathrm{abB}$ & $19.9 \pm 0.1 \mathrm{bB}$ & $18.9 \pm 0.3 \mathrm{cB}$ & $18.7 \pm 0.0 \mathrm{cB}$ \\
\hline Linoleic acid & $61.0 \pm 2.8 \mathrm{bA}$ & $63.1 \pm 0.4 \mathrm{aAB}$ & $63.2 \pm 0.1 \mathrm{aA}$ & $62.0 \pm 0.3 \mathrm{abA}$ & $63.1 \pm 0.4 \mathrm{aA}$ & $57.2 \pm 0.4 \mathrm{cA}$ & $56.7 \pm 0.3 \mathrm{cA}$ \\
\hline Linolenic acid & $0.1 \pm 0.0 \mathrm{cE}$ & $0.1 \pm 0.0 \mathrm{cE}$ & $0.1 \pm 0.0 \mathrm{cE}$ & $0.1 \pm 0.0 \mathrm{cE}$ & $0.1 \pm 0.0 \mathrm{cE}$ & $10.1 \pm 0.4 \mathrm{aC}$ & $9.4 \pm 0.0 \mathrm{bD}$ \\
\hline Arachidonic acid & $0.2 \pm 0.0 \mathrm{bE}$ & $0.2 \pm 0.0 \mathrm{bE}$ & ND & $0.2 \pm 0.0 \mathrm{bE}$ & $0.2 \pm 0.0 \mathrm{bE}$ & ND & $0.4 \pm 0.0 \mathrm{aF}$ \\
\hline Total & $100.0 \pm 0.0$ & $100.0 \pm 0.0$ & $100.0 \pm 0.0$ & $100.0 \pm 0.0$ & $100.0 \pm 0.0$ & $100.0 \pm 0.0$ & $100.0 \pm 0.0$ \\
\hline
\end{tabular}

ND not detected

Values are means $\pm \mathrm{SD}(\mathrm{n}=3)$. Means with different lower case letters $(\mathrm{a}, \mathrm{b}$, and $\mathrm{c})$ are significantly different between fermentation periods and with different upper case letters $(\mathrm{A}, \mathrm{B}$, and $\mathrm{C})$ are significantly different between compounds by Duncan's multiple range test at $p<0.01$

지 않았으나 Phenolic acids인 vanillic acid와 protocatechuic acid는 DPPH 라디칼 소거력과 상관성을 시사하였다[35].

\section{관능검사와 색도}

된장의 관능검사는 주관적인 방법인 $\mathrm{QDA}$ 로 색, 향기, 맛과 관 련된 항목을 평가하여 spider map으로 Table 4에 나타냈다. $\mathrm{QDA}$ 에 의한 된장의 갈색도(brown color)는 숙성 초기 12 개월 $7.1 \pm 1.3$ 에서 숙성 후기에 $14.0 \pm 0.4$ 로 높아졌다 $(p<0.01)$. 또한 된 장의 색은 객관적인 방법인 Hunter 색차계를 사용하여 측정했 다. 숙성기간 동안 된장의 $L, a, b$ 값이 모두 감소하였다 $(p$ $<0.01)$. 사진으로 제시한 것과 같이 된장의 밝기를 나타내는 $L$
값은 어두워지고, 적색의 $a$ 값과 노란색의 $b$ 값이 감소하여 이들 의 색은 흐려져서, 총체적으로 된장의 색은 어두운 갈색을 나 타내었다. Oh 등[36]은 이와 같은 된장 색의 변화는 저장기간 동안 된장의 성분들이 효소적·비효소적 갈색화 반응에 기인한 것이라고 하였다.

된장의 향기 평가에서 캐러멜 향기(caramel flavor)는 숙성 후 기에 $10.7 \pm 1.5$ 로 높아졌다 $(p<0.01)$. 이런 캐러멜 향기는 마이얄 반응에 의해 생성된 휘발성 향기성분으로 pyrazine류, aldehyde 류와 furan류 등에 기인한 것이다[26]. 메주 특유의 자극취를 측 정한 콩발효 향기(fermented soybean flavor)는 숙성 전 $5.1 \pm 1.8$ 에서 숙성 중기 $10.0 \pm 2.1$ 로 높아졌다 $(p<0.01)$. 시큼한 발 


\begin{tabular}{|c|c|c|c|c|c|c|c|}
\hline \multirow{3}{*}{$\begin{array}{l}\text { Free amino acids } \\
\qquad(\mathrm{mg} / 100 \mathrm{~g})\end{array}$} & \multicolumn{7}{|c|}{ Doenjang (Aging period, month) } \\
\hline & \multirow{2}{*}{ Before aging } & \multicolumn{2}{|c|}{ Initial phase } & \multicolumn{2}{|c|}{ Midphase } & \multicolumn{2}{|c|}{ Final phase } \\
\hline & & 6 & 12 & 18 & 24 & 30 & 36 \\
\hline \multicolumn{8}{|c|}{ Aliphatic amino acids } \\
\hline Glycine $^{\mathrm{b}}$ & $34.2 \pm 2.3 \mathrm{fIJK}$ & $87.4 \pm 2.0 \mathrm{efHJ}$ & $382.8 \pm 6.6 \mathrm{dH}$ & $1072.4 \pm 68.6 \mathrm{aI}$ & $877.9 \pm 18.8 \mathrm{bEF}$ & $762.0 \pm 29.2 \mathrm{cI}$ & $706.8 \pm 28.0 \mathrm{cIJ}$ \\
\hline Alanine $^{\mathrm{b}}$ & $77.9 \pm 7.4 \mathrm{fDE}$ & $237.7 \pm 6.2 \mathrm{eC}$ & $973.7 \pm 23.7 \mathrm{dC}$ & $2662.4 \pm 88.0 \mathrm{aB}$ & $2091.5 \pm 32.6 \mathrm{bB}$ & $1960.2 \pm 19.5 \mathrm{cDE}$ & $2143.5 \pm 98.0 \mathrm{bD}$ \\
\hline Valine $^{c}$ & $63.7 \pm 4.0 \mathrm{gEHG}$ & $150.3 \pm 3.0 \mathrm{fF}$ & $700.1 \pm 53.9 \mathrm{eDE}$ & $1533.7 \pm 12.4 \mathrm{cEF}$ & $1195.8 \pm 19.1 \mathrm{dD}$ & $1744.9 \pm 9.6 \mathrm{bEF}$ & $2054.2 \pm 102.2 \mathrm{aD}$ \\
\hline Leucine $^{c}$ & $143.3 \pm 13.3 \mathrm{fB}$ & $304.4 \pm 1.9 \mathrm{eB}$ & $1092.6 \pm 28.3 \mathrm{~dB}$ & $3826.2 \pm 39.8 \mathrm{aA}$ & $3084.6 \pm 93.4 \mathrm{cA}$ & $3407.9 \pm 34.9 \mathrm{bB}$ & $3089.4 \pm 125.7 \mathrm{cB}$ \\
\hline Isoleucine $^{\mathrm{c}}$ & $74.0 \pm 1.8 \mathrm{fDEF}$ & $170.2 \pm 0.6 \mathrm{eE}$ & $588.9 \pm 49.9 \mathrm{dFG}$ & $1439.8 \pm 77.2 \mathrm{bFG}$ & $1147.4 \pm 10.8 \mathrm{cDE}$ & $1603.6 \pm 51.9 \mathrm{aEF}$ & $1436.4 \pm 59.0 \mathrm{bEF}$ \\
\hline Sum & $393.0 \pm 19.7 \mathrm{f}$ & $950.0 \pm 11.1 \mathrm{e}$ & $3738.2 \pm 154.7 \mathrm{~d}$ & $10534.5 \pm 261.2 \mathrm{a}$ & $8397.2 \pm 174.7 \mathrm{c}$ & $9478.5 \pm 67.6 b$ & $9430.1 \pm 160.9 b$ \\
\hline \multicolumn{8}{|c|}{ Aromatic amino acids } \\
\hline Tyrosine* & $52.2 \pm 2.5 \mathrm{eGH}$ & $81.7 \pm 2.2 \mathrm{eIJ}$ & $81.8 \pm 11.9 \mathrm{eKL}$ & $683.3 \pm 22.6 \mathrm{cJK}$ & $534.5 \pm 5.5 \mathrm{dGH}$ & $1192.3 \pm 66.3 \mathrm{aGH}$ & $1030.1 \pm 5.1 \mathrm{bHJ}$ \\
\hline Tryptophane*,c & $43.1 \pm 1.3 \mathrm{cHIJ}$ & $99.0 \pm 7.3 \mathrm{bH}$ & $192.3 \pm 49.9 \mathrm{aJ}$ & $101.6 \pm 7.3 \mathrm{bN}$ & $86.9 \pm 0.7 \mathrm{bJ}$ & ND & ND \\
\hline Phenylalanine $e^{*, \mathrm{c}}$ & $111.8 \pm 7.9 \mathrm{gC}$ & $222.8 \pm 5.4 \mathrm{fD}$ & $649.8 \pm 14.1 \mathrm{eDEF}$ & $1289.9 \pm 30.2 \mathrm{cH}$ & $1025.1 \pm 6.4 \mathrm{dDE}$ & $2275.4 \pm 33.9 \mathrm{aD}$ & $2039.7 \pm 97.0 \mathrm{bD}$ \\
\hline Sum & $207.1 \pm 5.0 \mathrm{~g}$ & $403.6 \pm 10.5 f$ & $923.9 \pm 65.2 \mathrm{e}$ & $2074.8 \pm 60.1 \mathrm{c}$ & $1646.5 \pm 12.5 \mathrm{~d}$ & $3467.7 \pm 100.2 \mathrm{a}$ & $3069.8 \pm 102.1 \mathrm{~b}$ \\
\hline \multicolumn{8}{|c|}{ Hydroxy amino acids } \\
\hline Threonine $^{\mathrm{b}}$ & $46.3 \pm 4.1 \mathrm{fHI}$ & $117.8 \pm 1.6 \mathrm{fG}$ & $580.3 \pm 22.6 \mathrm{eFG}$ & $1380.6 \pm 43.4 \mathrm{aGH}$ & $1040.8 \pm 9.8 \mathrm{cDE}$ & $1201.2 \pm 10.2 \mathrm{bGH}$ & $769.2 \pm 97.6 \mathrm{dIJ}$ \\
\hline Serine $^{\mathrm{b}}$ & $64.7 \pm 3.8 \mathrm{fEFG}$ & $168.9 \pm 3.0 \mathrm{eE}$ & $713.5 \pm 16.2 \mathrm{dD}$ & $1572.9 \pm 61.2 \mathrm{bE}$ & $1245.2 \pm 25.8 \mathrm{cD}$ & 1661.1 $\pm 133.5 \mathrm{abEF}$ & $1697.4 \pm 26.0 \mathrm{aE}$ \\
\hline Sum & $111.0 \pm 4.8 \mathrm{f}$ & $286.7 \pm 4.4 \mathrm{e}$ & $1293.7 \pm 38.5 \mathrm{~d}$ & $2953.5 \pm 104.5 \mathrm{c}$ & $2286.0 \pm 35.6 \mathrm{a}$ & $2862.3 \pm 143.6 \mathrm{a}$ & $2466.6 \pm 123.5 b$ \\
\hline \multicolumn{8}{|l|}{ Acidic amino acids } \\
\hline Aspartic acid ${ }^{\mathrm{a}}$ & $58.5 \pm 5.2 \mathrm{fFGH}$ & $69.5 \pm 0.3 \mathrm{fJK}$ & $291.6 \pm 14.0 \mathrm{eI}$ & $652.4 \pm 30.5 \mathrm{cIKL}$ & $476.3 \pm 8.8 \mathrm{dGHI}$ & $1545.7 \pm 70.6 \mathrm{aFG}$ & $1084.4 \pm 65.0 \mathrm{bGH}$ \\
\hline Glutamic acid ${ }^{\mathrm{a}}$ & $190.5 \pm 7.4 \mathrm{fA}$ & $399.7 \pm 7.9 \mathrm{fA}$ & $1716.2 \pm 62.7 \mathrm{eA}$ & $3773.0 \pm 25.7 \mathrm{cA}$ & $2895.2 \pm 31.4 \mathrm{dA}$ & $6818.1 \pm 462.8 \mathrm{aA}$ & $6487.2 \pm 7.9 \mathrm{bA}$ \\
\hline Asparagine & 18.1 $\pm 1.4 \mathrm{eKLM}$ & $57.8 \pm 0.6 \mathrm{dK}$ & $313.8 \pm 20.2 \mathrm{cHI}$ & $739.0 \pm 23.7 \mathrm{aJ}$ & $616.8 \pm 38.1 \mathrm{bFG}$ & $45.3 \pm 0.4 \mathrm{deJ}$ & $47.3 \pm 0.5 \mathrm{deK}$ \\
\hline Glutamine & $16.7 \pm 1.4 \mathrm{dLM}$ & $19.6 \pm 1.1 \mathrm{dM}$ & $143.4 \pm 5.3 \mathrm{cJK}$ & $575.5 \pm 22.4 \mathrm{aKL}$ & $428.2 \pm 4.7 \mathrm{bGHI}$ & ND & ND \\
\hline Sum & $283.8 \pm 6.3 \mathrm{f}$ & $546.5 \pm 9.8 \mathrm{f}$ & $2465.1 \pm 98.3 \mathrm{e}$ & $5739.9 \pm 102.3 \mathrm{c}$ & $4416.6 \pm 83.0 \mathrm{~d}$ & $8409.2 \pm 533.7 \mathrm{a}$ & $7618.9 \pm 72.5 b$ \\
\hline \multicolumn{8}{|l|}{ 3asic amino acids } \\
\hline Histidine $e^{*, \mathrm{c}}$ & $27.1 \pm 0.7 \mathrm{eJKL}$ & $55.7 \pm 1.3 \mathrm{eK}$ & $179.9 \pm 4.7 \mathrm{dJ}$ & $552.4 \pm 28.5 \mathrm{cL}$ & $443.0 \pm 21.9 \mathrm{cGHI}$ & $842.0 \pm 4.7 \mathrm{aHI}$ & $673.7 \pm 164.4 \mathrm{bJ}$ \\
\hline Arginine & $82.4 \pm 5.3 \mathrm{eD}$ & $56.9 \pm 2.0 \mathrm{eK}$ & $308.7 \pm 3.4 \mathrm{dHI}$ & $672.5 \pm 36.6 \mathrm{bJK}$ & $502.2 \pm 18.9 \mathrm{cGHI}$ & $1201.5 \pm 103.4 \mathrm{aGH}$ & $1303.2 \pm 142.7 \mathrm{aFG}$ \\
\hline Lysine & $85.1 \pm 7.8 \mathrm{eD}$ & $171.3 \pm 3.4 \mathrm{eE}$ & $621.6 \pm 14.3 \mathrm{dEF}$ & $1954.3 \pm 32.8 \mathrm{bD}$ & $1622.7 \pm 98.2 \mathrm{cC}$ & $2710.0 \pm 5.6 \mathrm{aC}$ & $2039.7 \pm 97.0 \mathrm{bD}$ \\
\hline Sum & $194.6 \pm 4.8 \mathrm{f}$ & $283.9 \pm 4.4 \mathrm{f}$ & $1110.2 \pm 16.7 \mathrm{e}$ & $3179.2 \pm 97.9 \mathrm{c}$ & $2567.9 \pm 139.1 \mathrm{~d}$ & $4753.5 \pm 104.3 \mathrm{a}$ & $4016.6 \pm 210.0 \mathrm{~b}$ \\
\hline \multicolumn{8}{|c|}{ Sulfur-containing amino acids } \\
\hline Cysteine ${ }^{*, a}$ & $6.8 \pm 0.0 \mathrm{dM}$ & $6.9 \pm 0.3 \mathrm{Dm}$ & $22.6 \pm 1.3 \mathrm{cL}$ & $243.9 \pm 15.7 \mathrm{aM}$ & $196.9 \pm 5.1 \mathrm{bIJ}$ & ND & ND \\
\hline Methionine*,c & $17.4 \pm 1.5 \mathrm{eLM}$ & $35.9 \pm 1.1 \mathrm{eL}$ & $164.7 \pm 34.5 \mathrm{cIK}$ & $331.5 \pm 17.9 \mathrm{aM}$ & $282.5 \pm 2.1 \mathrm{bHIJ}$ & ND & $97.9 \pm 6.7 \mathrm{dK}$ \\
\hline Sum & $24.2 \pm 1.5 \mathrm{e}$ & $42.7 \pm 1.4 \mathrm{e}$ & $187.4 \pm 35.5 \mathrm{c}$ & $575.4 \pm 33.6 \mathrm{a}$ & $479.4 \pm 7.2 \mathrm{~b}$ & & $97.9 \pm 6.7 \mathrm{~d}$ \\
\hline \multicolumn{8}{|l|}{ mino amino acid } \\
\hline Proline ${ }^{\mathrm{b}}$ & $77.8 \pm 4.4 \mathrm{dDE}$ & $222.1 \pm 14.0 \mathrm{dD}$ & $523.5 \pm 20.9 \mathrm{cG}$ & $2405.5 \pm 13.6 \mathrm{aC}$ & $1691.6 \pm 414.6 \mathrm{bC}$ & $1919.0 \pm 23.5 \mathrm{bDEF}$ & $2600.8 \pm 73.4 \mathrm{aC}$ \\
\hline Sum & $77.8 \pm 4.4 \mathrm{~d}$ & $222.1 \pm 14.0 \mathrm{~d}$ & $523.5 \pm 20.9 \mathrm{c}$ & $2405.5 \pm 13.6 \mathrm{a}$ & $1691.6 \pm 414.6 \mathrm{~b}$ & $1919.0 \pm 23.5 b$ & $2600.8 \pm 73.4 \mathrm{a}$ \\
\hline TOTAL & $1291.5 \pm 28.2 \mathrm{~g}$ & $2735.5 \pm 10.2 \mathrm{f}$ & $10241.9 \pm 415.3 \mathrm{e}$ & $27462.8 \pm 673.1 \mathrm{c}$ & $21485.3 \pm 866.7 \mathrm{~d}$ & $30890.2 \pm 972.9 \mathrm{a}$ & $29300.6 \pm 169.0 \mathrm{~b}$ \\
\hline RSA* $^{*}$ & $258.4 \pm 4.0 \mathrm{~g}$ & $502.0 \pm 8.1 \mathrm{f}$ & $1291.2 \pm 104.4 \mathrm{e}$ & $3202.6 \pm 122.1 \mathrm{c}$ & $2568.9 \pm 41.6 \mathrm{~d}$ & $4309.7 \pm 95.5 \mathrm{a}$ & $3790.0 \pm 158.0 \mathrm{~b}$ \\
\hline
\end{tabular}

ND not detected. Values are means $\pm \mathrm{SD}(\mathrm{n}=3)$. Means with different lower case letters $(\mathrm{a}, \mathrm{b}$, and $\mathrm{c}$ ) are significantly different between fermentation periods and withdifferent upper case letters $(\mathrm{A}, \mathrm{B}$, and C) are significantly different between amino acids by Duncan's multiple range test at $p<0.01$

*RSA (Radical scavenging amino acids): adaptedfrom Elias et al. (2008)

${ }^{a}$ Umami, ${ }^{\mathrm{b}}$ Sweetness, ${ }^{\mathrm{c}}$ Sourness: adapted from Yang et al. (1992) and Lee et al. (2003) 


\begin{tabular}{|c|c|c|c|c|c|c|c|}
\hline & \multicolumn{7}{|c|}{ Doenjang (Aging period, month) } \\
\hline & \multirow{2}{*}{ Before aging } & \multicolumn{2}{|c|}{ Initial phase } & \multicolumn{2}{|c|}{ Midphase } & \multicolumn{2}{|c|}{ Final phase } \\
\hline & & 6 & 12 & 18 & 24 & 30 & 36 \\
\hline Total phenolic content $(\mathrm{mg} / \mathrm{L})$ & $1912.6 \pm 32.8 \mathrm{~d}$ & $2185.9 \pm 14.8 \mathrm{~d}$ & $8992.2 \pm 276.5 \mathrm{a}$ & $5597.3 \pm 166.9 \mathrm{~b}$ & $5203.3 \pm 186.4 \mathrm{c}$ & $5767.0 \pm 81.5 b$ & $5179.1 \pm 197.3 \mathrm{c}$ \\
\hline ABTS Radical scavenging capacity (\%) & $93.4 \pm 0.6 b$ & $93.5 \pm 0.1 b$ & $94.0 \pm 0.4 \mathrm{a}$ & $89.5 \pm 0.1 \mathrm{c}$ & $89.6 \pm 0.0 \mathrm{c}$ & $89.7 \pm 0.1 \mathrm{c}$ & $89.7 \pm 0.1 \mathrm{c}$ \\
\hline DPPH Radical scavenging capacity (\%) & $95.1 \pm 0.5 \mathrm{~d}$ & $99.3 \pm 0.2 \mathrm{a}$ & $96.1 \pm 0.1 \mathrm{~cd}$ & $96.5 \pm 0.6 b c$ & $97.4 \pm 0.7 b$ & $99.4 \pm 0.5 \mathrm{a}$ & $98.8 \pm 1.1 \mathrm{a}$ \\
\hline Reducing power (\%) & $1.2 \pm 0.2 \mathrm{~b}$ & $1.3 \pm 0.0 \mathrm{a}$ & $1.3 \pm 0.1 \mathrm{a}$ & $0.9 \pm 0.0 \mathrm{c}$ & $0.9 \pm 0.0 \mathrm{c}$ & $0.9 \pm 0.0 \mathrm{c}$ & $0.9 \pm 0.0 \mathrm{c}$ \\
\hline Lipid peroxidation inhibition (\%) & $94.3 \pm 1.1 \mathrm{~b}$ & $93.9 \pm 0.4 \mathrm{bc}$ & $95.3 \pm 0.3 \mathrm{a}$ & $94.2 \pm 0.1 \mathrm{~b}$ & $93.6 \pm 0.1 \mathrm{bc}$ & $93.2 \pm 0.1 \mathrm{c}$ & $93.9 \pm 0.1 \mathrm{bc}$ \\
\hline SOD-like activity (\%) & $74.4 \pm 1.9 \mathrm{c}$ & $77.7 \pm 5.0 \mathrm{c}$ & $85.6 \pm 1.6 b$ & $84.6 \pm 2.0 \mathrm{~b}$ & $91.8 \pm 3.2 \mathrm{a}$ & $87.1 \pm 3.5 \mathrm{ab}$ & $86.4 \pm 1.7 \mathrm{a}$ \\
\hline \multicolumn{8}{|l|}{ Nitrite scavenging capacity (\%) } \\
\hline pH 1.2 & $82.3 \pm 4.5 \mathrm{~b}$ & $98.3 \pm 0.3 \mathrm{a}$ & $97.1 \pm 0.2 \mathrm{a}$ & $97.0 \pm 0.2 \mathrm{a}$ & $97.3 \pm 0.1 \mathrm{a}$ & $97.4 \pm 0.1 \mathrm{a}$ & $97.5 \pm 0.1 \mathrm{a}$ \\
\hline $\mathrm{pH} 3.0$ & $74.6 \pm 1.1 \mathrm{e}$ & $87.6 \pm 2.1 \mathrm{~d}$ & $97.3 \pm 1.2 \mathrm{a}$ & $95.8 \pm 0.0 \mathrm{ab}$ & $92.2 \pm 0.2 \mathrm{c}$ & $94.4 \pm 0.1 \mathrm{~b}$ & $95.2 \pm 0.3 b$ \\
\hline $\mathrm{pH} 6.0$ & $40.1 \pm 3.7 b$ & $43.9 \pm 3.6 \mathrm{a}$ & $46.1 \pm 1.0 \mathrm{a}$ & $9.3 \pm 0.1 \mathrm{~d}$ & $13.3 \pm 0.2 \mathrm{c}$ & $12.1 \pm 0.2 \mathrm{~cd}$ & $11.2 \pm 0.3 \mathrm{~cd}$ \\
\hline
\end{tabular}

Values are means $\pm \mathrm{SD}(\mathrm{n}=3)$. Means with different $(\mathrm{a}, \mathrm{b}$, and $\mathrm{c})$ are significantly different between fermentation periods by Duncan's multiple range test at $p<0.01$

Table 4 Spider map of Doenjang showing by quantitative descriptive analysis and Hunter value

\begin{tabular}{ccc}
\hline \hline & Aging period (month) \\
Hunter Value \\
$\begin{array}{c}\text { Descriptive } \\
\text { Analysis }\end{array}$
\end{tabular}

Each value was expressed as means \pm sdof triplicates. Different letters $(\mathrm{a}, \mathrm{b}$, and $\mathrm{c}$ ) are significantly different between sample by Duncan's multiple range test at $p<0.01$ 


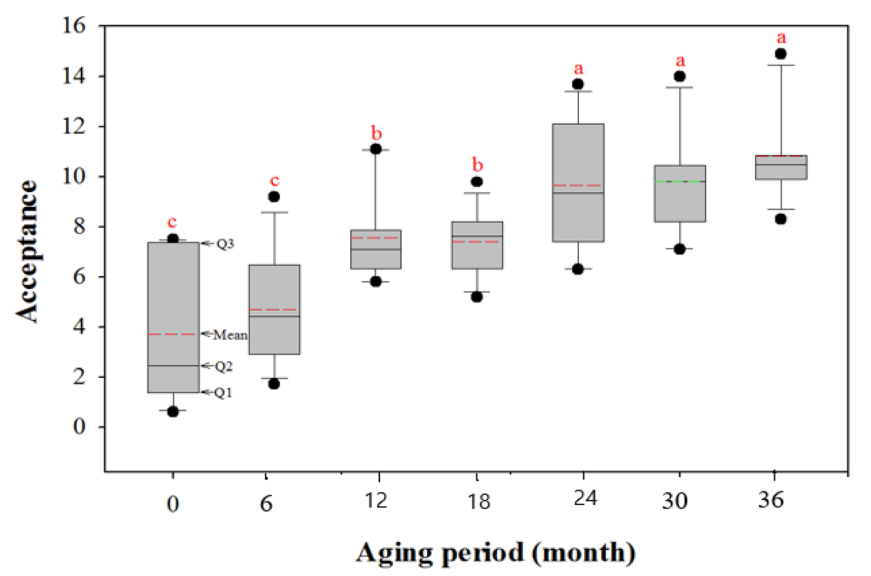

Fig. 1 Acceptance of Doenjang. Data $(n=12)$ are presented in a box. The gray bars represent the 25 th to 75 th percentiles. Center horizontal solid line and dotted line indicate median and mean. The closed dot represents outliers. Whiskers show the range of the observed values that fell within 1.5 times the interquartile range. Different letters (a, b, and c) are significantly different between samples by Duncan's multiple range test at $p<0.01$

효 향기를 측정하기 위한 치즈 향기(cheese flavor)는 숙성 중기 이후부터 $9.1 \pm 1.8$ 로 높게 나타났다 $(p<0.01)$.

된장의 맛에 대한 평가에서 단맛은 숙성 전 $1.2 \pm 0.7$ 에서 지 속적으로 높아져서 숙성 후기에 $6.0 \pm 1.5$ 의 높은 값으로 평가되 었다 $(p<0.01)$. Sousa 등[37]은 단맛의 경우에는 대두의 탄수화 물이 당화효소의 가수분해로 생성된 당분과 단맛을 가진 아미 노산인 glycine, alanine, serine, lysine, proline, threonine 등의 증가하여 생성된 것이라고 하엿다.신맛도 숙성 전 $2.4 \pm 1.5$ 에서 숙성 후기에 $9.4 \pm 2.3$ 로 높아졌다 $(p<0.01)$. 이는 Table 2의 유기 산 분석에서도 숙성 후기에 lactic acid, malic acid가 증가한 것을 확인할 수 있었다. Park 등[38]은 된장의 신맛은 젖산균에 의해 생성된 lactic acid, malic acid 등의 유기산에 의한 영향 이라고 하였다. 짠맛은 숙성 전 $10.9 \pm 2.0$ 에서 숙성 후기에 $8.5 \pm 1.5$ 로 감소하는 경향을 보였으며, 감칠맛은 숙성 기간 동안 유의적으로 증가하는 경향을 나타냈다 $(p<0.01)$.

Fig. 1은 된장의 기호도를 상자모양으로 나타냈다[37]. 기호도 는 된장의 숙성기간이 길어질수록 높아졌고, 숙성 후기에는 기 호도의 분포가 좁아졌다 $(p<0.01)$. 이는 된장의 기호도는 숙성 후기에 선호도가 높고, 관능검사자 개인 별 기호도의 차이에 의 한 오차가 크지 않다는 것을 뒷받침해 주고 있다. 기호도와 갈 색도, 콩발효 향기, 치즈 향기, 캐러멜 향기, 단맛, 신맛, 감칠맛 등의 모든 관능 평가 결과와 숙성 기간은 높은 양의 상관관계 를 보였다 $(p<0.01)$. 된장에 기호도를 예측하는 맛 성분 반응 변 수에 관한 선행 연구에서 Park 등[40]은 단맛과 쓴맛이, Byun 등[41]은 $\mathrm{pH}$ 와 짠맛이 된장의 기호도에 영향을 미치는 것으로 보고 된 바가 있으나, 본 연구의 다중회귀분석 결과에서는 감 칠맛과 갈색도가 기호도에 가장 큰 영향을 주는 요인으로 나타 났다. 숙성 초기에는 된장의 짠맛이 강하지만 숙성이 진행됨에 따라 짠맛을 제외한 다른 관능적인 항목의 값이 증가하여 최종 적으로는 맛의 균형이 조화로워진다. Table 3 의 유리 아미노산 분석에서도 감칠맛과 관련된 glutamic acid, cysteine이 숙성기
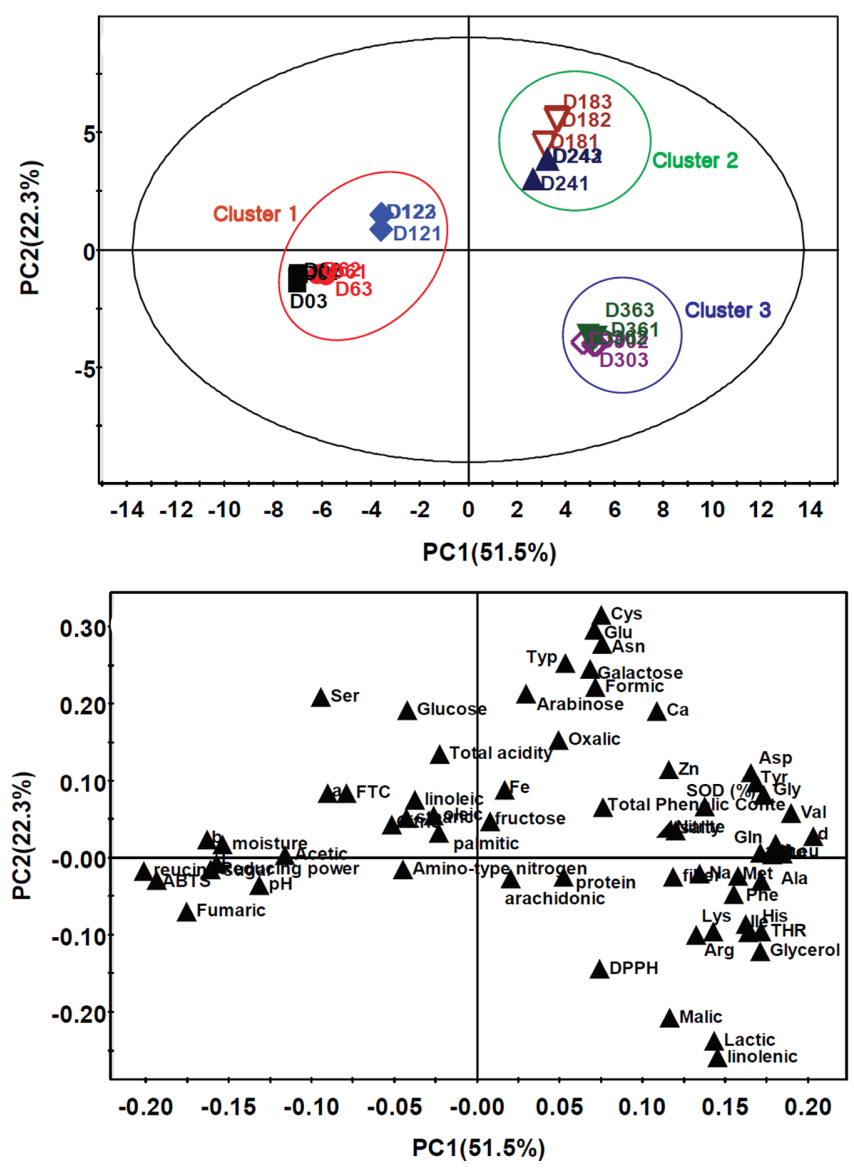

Fig. 2 Principal component analysis (PCA) score plot (A) and loading plot (B) of Doenjang. The variables consist of proximate composition, physicochemical properties and antioxidant capacity. Cluster 1: D0 (Before aging), D6 (6 months aging), D12(12 months aging); Cluster 2: D 18 (18 months aging), D 24 (24 months aging); Cluster 3: D 30 (30 months aging), D36 (36 months aging)

간 동안 증가하는 것을 확인할 수 있다. 특히 감칠맛과 갈색이 된장의 기호도에 가장 큰 영향을 주는 요인으로 나타났다 $(p$ $<0.01)$. 본 연구에서 숙성초기에는 된장의 향기와 관련된 항목 인 콩발효 향기, 치즈 향기, 캐러멜 향기에서 유의적인 변화를 보였고, 숙성 중기에는 된장의 색과 맛을 평가한 항목인 갈색 도, 단맛, 신맛, 감칠맛에서 유의적인 차를 나타냈다. 이와 같은 된장의 색, 향기와 맛의 조화가 완성되는 숙성 중기인 24개월 이 관능적으로 섭취하기 가장 적합한 시기로 나타났다.

\section{주성분 분석과 $\boldsymbol{k}$-means cluster analysis}

된장의 이화학적 성분과 항산화력의 데이터를 기반으로 한 PCA 와 $k$-means clustering결과를 Fig. 2 에 제시하였다. 데이터의 전 체 변동은 숙성 기간을 설명하는 $\mathrm{PC} 1$ 이 $51.6 \%$ 였고, 된장의 구 성성분의 변화가 어느 시기에 높은지 설명하는 $\mathrm{PC} 2$ 는 $22.3 \%$ 로 분석되었다. Fig. 2의 score plot (A)에서 $k$-means는 숙성 $0-12$ 개월이 제 1 사분면과 제 3 사분면에 걸쳐 위치하는 cluster 1 , 숙 성 18-24개월이 2사분면에 위치하는 cluster 2, 30-36개월이 제 4사분면에 위치하는 cluster 3 의 세 개 그룹으로 구분되었다. 
Fig. 2의 score plot (A)의 cluster를 loading plot (B)에 대응하 여 숙성기간 별 된장의 품질 특성의 요인들을 확인하였다. 먼 저 제 1 사분면과 제 3 사분면에 걸쳐 위치하는 된장의 cluster 1 은 숙성 초기인 0-12개월 된장으로 수분, $\mathrm{pH}, \mathrm{ABTS}$ 라디칼 소거 력과 환원력이 분포되었다. 다음으로 제 2 사분면에 있는 숙성 중 기 18-24개월의 cluster 2에서는 라디칼 소거 아미노산인 cysteine, glutamic acid, tryptophane, 그리고 된장의 맛과 관련 된 galactose, glucose, arabinose 와 총산도 등이 분포되었다. Kang 등[42]은 일반적으로 발효 과정 중 된장의 아미노산의 함 량이 높을수록 된장은 품질과 맛이 뛰어나다고 평가하는 경향 이 있다고 하였다. 숙성 중기에는 감칠맛이 10 점으로 가장 높 은 평가를 나타냈고, 신맛과 향기 항목의 평가에서 9점 이상의 높은 점수를 Table 4의 $\mathrm{QDA}$ 관능검사에서 확인할 수 있다. 이 는 숙성 18 개월에 된장의 맛이 좋아지기 시작하여 숙성 중기인 24 개월에는 된장의 색, 향기와 맛의 조화가 완성되는 시기로 섭 취하기 가장 적합한 시기라는 것을 알 수 있다. 마지막으로 제 4사분면에 있는 숙성 후기 30-36개월의 cluster 3은 aspartic acid, glycine, valine 등의 아미노산, 그리고 맛과 저장에 영향 을 미치는 lactic acid, malic acid가 분포되었다. Table 2의 아 미노산 분석에서 이들 아미노산들은 숙성 기간 동안 계속적으 로 증가하여 숙성 후기에는 높은 함량을 나타냈다. Table 1의 유기산 분석에서 lactic acid, malic acid의 함량이 36 개월에 $33404.5 \mathrm{mg} / 100 \mathrm{~g}$ 으로 증가했다. 그리고 관능검사에서 감칠맛, 신 맛, 향기 항목 등에서 10점 이상의 높은 평가 점수를 보였다. 숙 성 후기인 제4사분면에서는 관능적 측면 이외에도 건강기능성 과 관련된 총 페놀 함량, $\mathrm{SOD}$ 유사활성, $\mathrm{DPPH}$ 라디칼 소거력, 라디칼 소거 아미노산인 tyrosine, phenylalanine, histidine, aspartic acid 요인들이 분포되어 있다. 이상의 주성분 분석과 $k$ means clustering의 종합적인 결과를 보면 숙성 중기인 24개월 에는 된장의 색, 향기와 맛의 조화가 완성되는 시기로 섭취하 기 가장 적합한 시기라는 것을 알 수 있다. 그리고 된장의 맛 과 건강 기능적 측면을 동시에 고려한다면 숙성 30 개월 이후가 된장의 최적 섭취 시기라고 할 수 있다. 본 연구에서 한국 전 통 된장을 제조하여 3 년 동안 자연조건에서 저장하면서 관능적 인 요인과 건강기능성 요인들을 관찰하였다. 본 실험에서 도출 하지 못한 한계를 가진 부분과 3 년 이상 숙성한 한국 전통 된 장에 관한 연구는 차후의 연구과제로 남기고자 한다.

\section{초 록}

된장의 최적 섭취 기간을 판단하기 위해 원료 대두로부터 3년 동안 발효 숙성 하면서 6개월 단위로 시료를 채취하여 분석하 였다. 이화학적 분석, 항산화력과 관능 검사를 주성분분석과 $k$ 평균 군집 분석하여 종합적인 품질 특성을 평가하였다. 된장의 품질 특성은 $\mathrm{PCA}$ 에 의해 1 년 간격으로 큰 변화가 확인되었고, 군집 분석에 의해 숙성 기간에 따라 각각 cluster $1,2,3$ 의 군 집으로 분류되었다. 건강기능성과 관련된 항산화력으로 총 페놀 함량, SOD 유사활성, DPPH 라디칼 소거 능력은 cluster 3에서 높았다. Cluster 3 에서는 맛과 관련된 관능 평가 항목과 유리아 미노산, 유기산 등도 높게 나타났다. 기호도 평가도 cluster 3에 서 높게 나타났고 기호도에 가장 큰 영향을 준 관능 항목 요인
은 감칠맛과 갈색이었다. 따라서 된장은 숙성 12 개월 이후부터 섭취 가능하지만 된장의 맛과 건강 기능적 측면을 동시에 고려 한다면 숙성 30 개월 이후가 된장의 최적 섭취 시기라고 할 수 있다.

Keywords 관능평가 - 된장 - 품질특성 - 항산화력

감사의 글 이 논문은 2017년도 가톨릭대학교 교내연구비 지원으로 수행된 연구입니다.

\section{References}

1. Yoon DI (2007) Study on the Asian fermented soybean sauce culture. Asian Comp Folk Soci 34: 155-215

2. Lim SY, Rhee SH, Park KY (2005) Effect of solvent fractions from methanol extract of Doenjang on inhibition of growth and DNA synthesis of human cancer cells. J Life Sci 15: 685-691

3. Lee SM, Chang HC (2009) Growth-inhibitory effect of the solar saltDoenjang on cancer cells, AGS and HT-29. J Korean Soc Food Sci Nut 38: 1664-1671

4. Jung KO, Park SY, Park KY (2006) Longer aging time increase the anticancer and antimetastatic properties of Doenjang. Nutrition 22: 539 545

5. Roh CH, Lee SJ, Nasir Uddin SM, Kim JK, Kan CK (2015) Characterization of antiobesity compounds from soybean paste. Eur Food Res Technol 240: 865-869

6. Park KY, Jung KO (2005) Fermented soybean products as functional foods: functional properties of Doenjang (fermented soybean paste). In: Shi J, Ho CT, and Shahidi F (ed) Asian Functional Foods, CRC Press, Boca Raton

7. Jo SJ, Hong CO, Yang SY, Choi KK, Kim HK, Yang H, Lee KW (2011) Changes in contents of $\gamma$-aminobutyric acid (GABA) and isoflavones in traditional Korean Doenjang by ripening periods. J Korean Soc Food Sci Nutr 40: 557-564

8. Oh SJ, Lee HJ, Lee SJ, Chung SH, Nak JS (2014) Evaluation of Quality Characteristics and Antioxidant Activities from Doenjang Ripened for 30 Years. J of Agri \& Life Sci 48: 265-283

9. $\mathrm{Ku} \mathrm{KK}$, Park KM, Kim HJ, Kim YS, Koo MS (2014) Quality characteristics of Doenjang by aging period. J Korean Soc Food Sci Nut 43: $720-728$

10. Tian T, Jun-rui WU, Xi-qing YUE (2014) Study on the texture change and correlation of soybean paste during natural fermentation. Food and Fermentation Industries 40: 27-31

11. Lee SM, Lee S, Singh D, Oh JY, Jeon EJ, Ryu HS, Lee DW, Kim BS, Lee $\mathrm{CH}$ (2017) Comparative evaluation of microbial diversity and metabolite profiles in Doenjang, a fermented soybean paste, during the two different industrial manufacturing processes. Food chem 221: 15781586

12. Park KY, Hwang KM, Jung KO, Lee KB (2002) Studies on the standardization of Doenjang (Korean soybean paste) 1. Standardization of manufacturing method of Doenjang by literatures. J Korean Soc Food Sci Nutr 31: 343-350

13. Ministry of food and drug safety (MFDS) (2012) Korean food standards codex, CheongJu

14. Chang M, Kim IC, Chang HC (2010) Effect of solar salt on the quality characteristics of Doenjang. J Korean Soc Food Sci Nutr 39: 116-124

15. Do YS, Whang HJ, Ku JE, Yoon KR (2005) Organic acids content of the selected Korean Apple Cultivars. Korean J Food Sci Technol 37: 922 927

16. Kang YH, Park YK, Lee GD (1996) The nitrite scavenging and electron donating ability of phenolic compounds. Korean J Food Sci Technol 28: 
232-239

17. Zoecklein BW, Fugelsang KC, Gump BH, Nury FS (1990) Production wine analysis. Van Nostrad Reinhold, New York

18. Verzelloni E, Tagliazucchi D, Conte A (2007) Relationship between the antioxidant properties and the phenolic and flavonoid content in traditional balsamic vinegar. Food Chem 105: 564-571

19. Xu Q, Tao W, Ao Z (2007) Antioxidant activity of vinegar melanoidins. Food Chem 102: 841-849

20. Zin ZM, Abdul-Hamid A, Osman A (2002) Antioxidative activity of extracts from Mengkudu (Morinda Citrifolia L.) root, fruit and leaf. Food Chem 78: 227-231

21. Lim JA, Na YS, Beak SH (2004) Antioxidative activity and nitrite scavenging ability of ethanol extract from Phyllostachys bambusoides. Korean J Food Sci Technol 36: 306-310

22. Choi JH, Kwon SH, Lee SW, Nam SH, Choi SD, Park SK (2003) Quality properties of capsule type Meju prepared with Aspergillus oryzae. Korean Journal of Food Preservation. 10: 339-346

23. Park GS, An SH, Choi KH, Jeoung JS, Park CS, Choi MA (2003) Preparation of the functional beverages by fermentation and its sensory characteristics. Korean J Soc Food Sci 16: 663-669

24. Hutchings JS (1994) Instrumental specification. In Food Color and Appearance. Blackie Academic \& Professional, Bedford

25. Lawless HT, Heymann H (1998) Sensory evaluation of food (Principles and practices): Data relationships and multivariate applications. Aspen Publishers Inc., New York

26. Kim HK (2010) Sensory characteristics and consumer acceptability of fermented soybean paste (Doenjang) products. Dissertation, Ewha Womans University

27. Kwak EJ, Park WS, Lim SI (2003) Color and quality properties of Doenjang added with citric acid and phytic acid. Korean J Food Sci Technol 35(3): 455-460

28. No JD, Lee DH, Lee DH, Choi SY, Kim NM, Lee JS (2006) Changes of Quality and Physiological Functionality during the Fermentation of Doenjang Made by Isolated Nuruk Mold and Commercial Nuruk Mold. J Korean Soc Food Sci Nutr 35(8): 1025-1030

29. Lee JS, Kwon SJ, Chung SW, Choi YJ, Yo JY, Chung DH (1996) Changes of microorganisms, enzyme activities and major components during the fermentation of Korean traditional Doenjang and Kochujang. J Korea Appl Microbiol Biotechnol 24: 247-253
30. Oh GS, Kang KJ, Hong YP, An YS, Lee HM (2003) Distribution of organic acids in traditional and modified fermented foods. J Korean Soc Food Sci Nutr 32: 1177-1185

31. Chung HY, Fung PK, Kim JS (2005) Aroma impact components in commercial plain sufu. J Agr Food Chem 53: 1684-1691

32. Yoon WJ, Lee SW, Moon HK, Moon JN, Kim BG, Kim BJ, Kim GY (2011) Quality characteristics of traditional Soybean Paste (Doenjang) manufactured with mixed beans. J East Asian Soc Dietary Life 21: 375 384

33. Elias RJ, Kellerby SS, Decker EA (2008) Antioxidant activity of proteins and peptides. Crit Rev Food Sci Nutr 48: 430-441

34. Kwon SH, Shon MY (2004) Antioxidant and anticarcinogenic effects of traditional Doenjang during maturation periods. Korean J Food Preserv 11: $461-467$

35. Chai C, Ju HK, Kim SC, Park JH, Lim JH, Kwon SW, Lee JM (2012) Determination of bioactive compounds in fermented soybean products using GC/MS and further investigation of correlation of their bioactivities. J Chromatogr B Analyst Technol Biomed Life Sci 880: 4249

36. Oh HJ, Kim CS (2007) Antioxidant and Nitrite Scavenging Ability of Fermented Soybean Foods (Chungkukjang, Doenjang). Korean Soc Food Sci Nutr. 36: 1503-1510

37. Sousa MJ, Ardo Y, Mcsweeneya PLH (2001) Advances in the study of proteolysis during cheese ripening. International Dairy Journal 11: 327345

38. Park SK, Seo KI, Shon MY, Moon JS, Lee YH (2000) Quality characteristics of home-made Doenjang, a traditional Korean soybean paste. Korean J Soc Food Sci 16: 121-127

39. Larsen RD (1985) Box-and-whisker plots. J Chem Educ 62: 302-312

40. Park HK, Kim JK (2008) Optimal manufacturing conditions for Korean soybean paste and soy sauce, using Aspergillus oryzae AJ 100 as a flavor improver. Food Soc Biotechnol 17: 208-211

41. Byun MW, Nam TG, Lee GH (2015) Physicochemical and sensory characteristics of Doenjang made with various concentrations of salt solution. J Korean Soc Food Sci Nut 44: 1525-1530

42. Kang HJ, Kim JH, Kim RR, Kim KS, Hong SP (2016) Quality characteristics and composition profile of Traditional Doenjang and Manufactured Doenjang during storage time. Korean J Food Nut 29: 785-794 